\title{
Construction Emphases and Quality Control of Gymnasium Plastic Track
}

\author{
Yarong Zheng*
}

Xi'an University of Posts \& Telecommunications, China

\begin{abstract}
Strict control over the construction emphases of plastic track is the best way to ensure construction quality. This paper makes brief introduction to the construction emphases, construction process, preparations before construction and construction procedure of plastic track, and also makes brief introduction to quality control criteria, mix ratio, and quality control of plastic track, so as to further improve the construction quality of gymnasium plastic track.
\end{abstract}

Keywords: Construction emphases, gymnasium, plastic track, quality control.

\section{INTRODUCTION}

In recent years, with fast social and economic development, people's living level and quality are improved visibly. Hence, people have higher requirements for physical education facilities of colleges, universities, middle schools and primary schools. And the construction of gymnasium track is the basic work of the construction of physical education facilities of colleges, universities, middle schools and primary schools. Plastic track has complex construction flow and has higher requirements for construction precision and quality, which increases the difficulty of quality control. During the construction of plastic track, curve, slope, marking, etc., should meet the special requirements of sport technique. During construction quality control, professional management team and high-quality competent technicians should be responsible for construction control and completion acceptance, so as to ensure the construction quality of plastic track meets the construction specifications and assure the durability and ruggedness of plastic track. This paper is to make detailed discuss on construction emphases and quality control of gymnasium plastic track.

\section{CONSTRUCTION EMPHASS OF PLASTIC TRACK}

During the construction of plastic track, there is much work which needs key control. Plastic track should have sufficient abrasion resistance and enough service life, be able to bear exogenous shocks, and have sound sport stability. During the construction quality control, common problems in all construction phases should be controlled effectively, so as to reach the expected construction quality. Reliable foundation and durable surface course are obbligato parts for ensuring construction quality [1]. For instance, the construction quality of three basic elements of plastic track, curve, elevation and gradient, directly depends upon the construction quality of basic construction. In addition to this, the combination of basic construction and plastic surface course, as well as sport index construction of plastic surface course are also the construction emphases of plastic track. During the construction of plastic track, these construction emphases should be controlled strictly, so as to ensure the construction quality of plastic track and make its durability and stability meet construction requirements.

\section{CONSTRUCTION PROCESS}

During the construction of plastic track, to ensure the construction quality of construction emphases and strictly control the construction quality of plastic track, the construction process should be cleared before construction, so as to control construction quality strictly according to construction process [2]. See Fig. (1) for construction process of plastic track.

In the construction process of plastic track, cushion course construction, base course paving and surface course construction (mixing for surface course, mixing and surface course coating) are the construction emphases of the plastic track, and they should be controlled effectively during construction quality control, so as to ensure the construction quality meets construction requirements.

\section{PREPARATIONS BEFORE CONSTRUCTION PROCESS}

\subsection{Preparations Before Construction}

\subsubsection{Source of Materials}

Before the construction of plastic track, detailed and allround inspection on the quality, specification and property of all construction materials should be done. As to some major materials, test and research should be done during the inspection [3]. The material of plastic track should pass the detection of National Athletic Equipment Supervision Center, so as to ensure its physical property indexes meet the relevant national requirements as well as the requirements of IAAF. Simultaneously, during the purchase of materials, to ensure the quality, specification and property of materials meet construction requirements, the materials should be purchased from regular and large-scale manufacturers, and the 


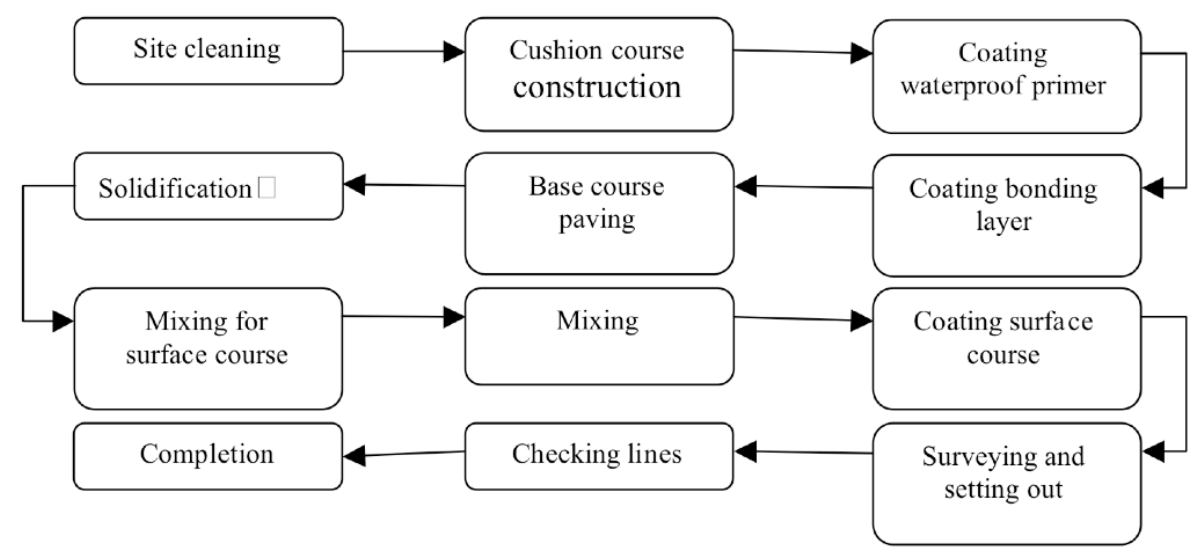

Fig. (1). Construction process of plastic track.

products without date of production, certificate of fitness and manufacturer information are not allowed, so as to avoid quality and safety problems.

\subsubsection{Detailed Inspection on Construction Equipment}

During the construction of plastic track, to effectively control construction quality, detailed inspection on construction equipment, such as mixer, high-pressure spray gun, guiding rule, steel rule, theodolite, paver, angle grinder, platform scale, electric portable drill, air compressor and bucket carrier, should be done, so as to ensure that they are in good condition and avoid the influence on construction. Simultaneously, the debugging and maintenance of construction equipment should also be done during construction.

\subsubsection{Know About Construction Drawings and Construc- tion Scheme in Detail}

Before the construction of plastic track, project manager, construction manager and technicians should know about the relevant materials, such as construction drawings and construction scheme, as well as the linkage of all specialties and construction processes. Simultaneously, test and research should be done during construction management, so as to effectively resolve construction problems.

\subsubsection{Draw Construction Plan}

Before the construction of plastic track, construction manager and technicians should draw layout plan of the construction site, so as to effectively plan construction area, material stacking site and equipment running route and avoid the influence on construction.

\subsubsection{Position Datum Point}

When positioning datum point, total station, theodolite, $100 \mathrm{~m}$ steel rule, level gage, etc. should be used for positioning, so as to ensure the accuracy and effectiveness.

\subsubsection{Survey and Set Out}

After checking the positioning of datum point, surveying and setting out should be done. Construction lines refer to the precast pavement datum lines for plastic track, and they should be set out accurately and marked with black marking pen. During the surveying and setting out, the first and outermost construction lines should be surveyed and set out. Before surveying and setting out, the gradient requirements for track and curve should be met effectively. To ensure the accuracy of surveying and setting out, Level-I steel rule which meets GB10633 should be used to check the axis. The time axis should be elongated $6 \mathrm{~m}$ outwards when surveying and setting out.

\subsubsection{Elevation}

When controlling elevation, elevation grid and ultraminiature positioning should be laid out accurately. The control effect of all special elevation points in the gymnasium should be enhanced, including main runway watershed, internal and external drainage ditches. The elevation positions of $110 \mathrm{~m}$ hurdles should be controlled. Since the elevation of starting and ending line is special, independent detection and orientation and control scheme should be taken. In south and north semicircles, slope-making on both sides should be done from the center of the internal drainage ditch. Drainage structure layer should be controlled within the range of design elevation, and independent elevation control scheme should be adopted. Generally, south and north semicircles are mainly mixed-use district of track and field athletics. When positioning small fields and controlling elevation, observation should be done carefully.

\subsection{Construction Process For Paving Plastic Track}

See Fig. (2) for the construction process for paving plastic track. See Fig. (3) for the construction drawing for paving plastic track.

During the paving of plastic track, besides knowing about paving construction process in detail, paving construction technology should also be known in detail, and the notes for construction technologies should be emphasized. See Table 1 for the details of plastic track construction technology.

During the paving of plastic track, paving construction technology should be controlled strictly, construction should be done according to paving construction process, so as to effectively ensure the construction quality as well as the durability and abrasion resistance. 


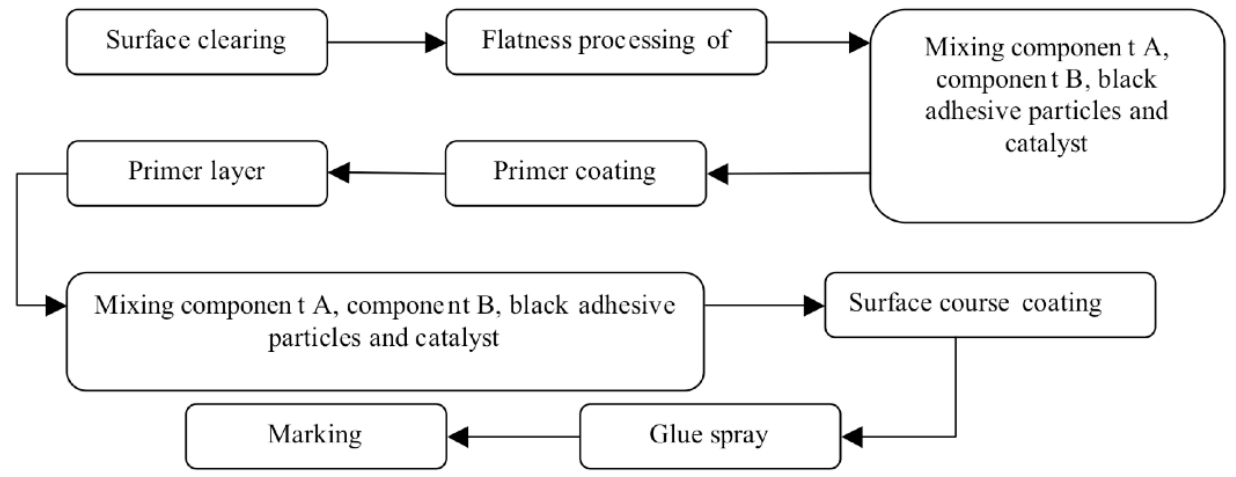

Fig. (2). Construction process for paving plastic track.

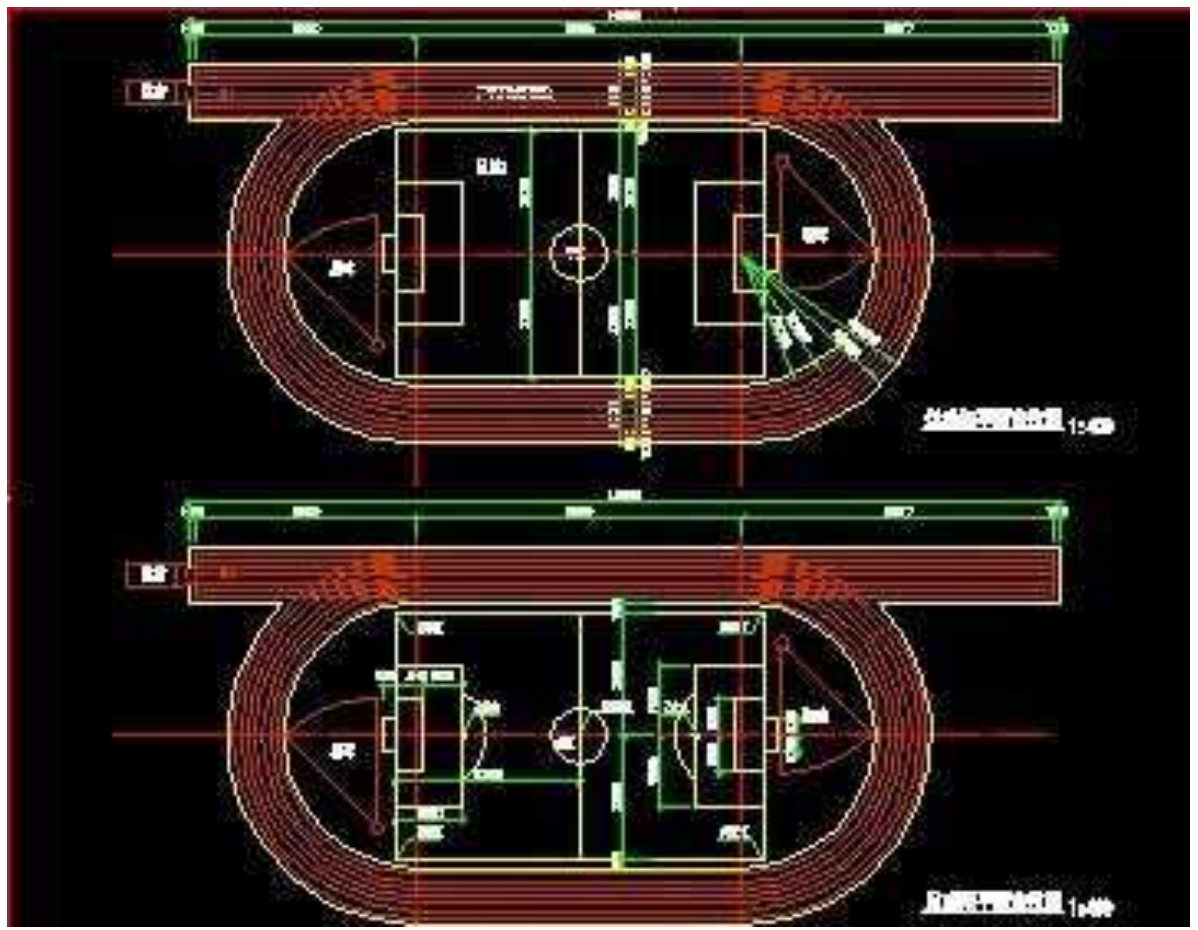

Fig. (3). Construction drawing for paving plastic track.

Table 1. Details of plastic track construction technology.

\begin{tabular}{|c|c|c|}
\hline $\begin{array}{c}\text { Construction } \\
\text { Technology }\end{array}$ & Details & Advantages \\
\hline \hline $\begin{array}{c}\text { Base surface } \\
\text { processing }\end{array}$ & $\begin{array}{c}\text { Mix components A and B of polyurethane } \\
\text { rubber and scrape the whole track }\end{array}$ & $\begin{array}{c}\text { Prevent leakage, increase the adhesive force of plastic surface and base surface, } \\
\text { improve the construction quality and elongate the serve life }\end{array}$ \\
\hline Material numbering & $\begin{array}{c}\text { Sequence components A and B of polyu- } \\
\text { rethane rubber according to production lot } \\
\text { number }\end{array}$ & $\begin{array}{c}\text { Contribute to the successful conduction of sampling, on-site gelatinization test and } \\
\text { wiredrawing test }\end{array}$ \\
\hline $\begin{array}{c}\text { Survey and draw } \\
\text { baseline }\end{array}$ & $\begin{array}{c}\text { Survey and draw boundary on asphalt } \\
\text { concrete according to the preset scheme, } \\
\text { divide the track into strips, and pave in } \\
\text { strips }\end{array}$ & $\begin{array}{c}\text { Contribute to reasonably arranging the workload of each worker, ensure water } \\
\text { supply and joint construction meet requirements, and conform to the construction } \\
\text { procedure of paving internal circle first and external circle later }\end{array}$ \\
\hline $\begin{array}{c}\text { Count semi-finished } \\
\text { products }\end{array}$ & $\begin{array}{c}\text { Count the semi-finished products needed } \\
\text { according to the paving area }\end{array}$ & $\begin{array}{c}\text { Can hoist components A and B onto the operating platform and place as per lots, } \\
\text { place the black adhesive particles and catalyst needed at proper position on the } \\
\text { operating platform, mix and feed them, so as to ensure the successful construction } \\
\text { and construction quality }\end{array}$ \\
\hline
\end{tabular}


Table 1. Contd......

\begin{tabular}{|c|c|c|}
\hline $\begin{array}{c}\text { Construction } \\
\text { Technology }\end{array}$ & Details & Advantages \\
\hline \hline Paving & $\begin{array}{c}\text { Pave prepared rubber adhesive evenly into } \\
\text { mould cavity }\end{array}$ & $\begin{array}{c}\text { When paving, the scaleplates mounted on both sides of the floating rule which is } \\
\text { used to control thickness should be inspected at all times. If the thickness fails to } \\
\text { meet the required thickness, adjustment should be done in time to ensure construc- } \\
\text { tion quality }\end{array}$ \\
\hline $\begin{array}{c}\text { Coating colloidal } \\
\text { particles }\end{array}$ & $\begin{array}{c}\text { Coat colloidal particles according to the } \\
\text { solidification situation }\end{array}$ & $\begin{array}{c}\text { When coating colloidal particles, pay attention to the solidification situation and } \\
\text { control the coating time according to experience. If early, spared some colloidal } \\
\text { particles at the place where colloidal particles sunk; if late, measures should be } \\
\text { taken in time to ensure the entire property of the plastic track }\end{array}$ \\
\hline $\begin{array}{c}\text { Coating colloidal } \\
\text { particles }\end{array}$ & $\begin{array}{c}\text { Make effective control during the process } \\
\text { of coating colloidal particles }\end{array}$ & $\begin{array}{c}\text { Coat and compress colloidal particles and pat with broom, so as to make lower } \\
\text { colloidal particles insert colloidal particles. If the coating is late, the colloidal parti- } \\
\text { cles will not disperse, scrape off adhesive cement and coat colloidal particles, so as } \\
\text { to ensure the abrasion resistance }\end{array}$ \\
\hline
\end{tabular}

\section{QUALITY CONTROL CRITERIA OF PLASTIC TRACK}

\subsection{Material of Track}

National Athletic Equipment Supervision Center will check whether the materials of plastic track meet the requirements of Plastic Track and IAAF will also do this, so as to ensure the quality of materials meets the requirements.

\subsection{Product Quality Criteria}

The product should pass the both authentication of T80 09002 international and domestic quality systems. Complete detection devices and instruments should be used in construction to check product quality, so as to ensure the accuracy of all properties [4].

\subsection{Field Index}

The indexes of the field for track and field athletics should conform to (c) Technical Requirements for Major Match, Item 1 Holding, Clause 12, IAAF Track and Field Facilities Manual.

\section{MIX RATIO AND QUALITY CONTROL}

When preparing mixture, inspection or sampling test should be done for the materials on site, such as asphalt, sand, mineral powder, aggregate chips, stone materials, etc., and the heating temperature of asphalt should also be controlled within the required range. Generally, unless otherwise specified, the temperature should range from $150^{\circ} \mathrm{C}$ to $170^{\circ} \mathrm{C}$, and that of aggregate should range from $160^{\circ} \mathrm{C}$ to $180^{\circ} \mathrm{C}$. The ex-factory temperature of temperate materials should range from $140{ }^{\circ} \mathrm{C}$ to $165^{\circ} \mathrm{C}$. If the ex-factory temperature is too high, the temperate materials should be remade. When delivered to the construction site, the temperature of the temperate materials should not be lower than $120^{\circ} \mathrm{C}$ to $150^{\circ} \mathrm{C}$. Machinery should be used to roll asphalt concrete. Rolling should be done in three phases, initial rolling, secondary rolling and final rolling. Rolling should be done from side to center and from low to high $[5,6]$. When rolling, the temperature of asphalt concrete should be con- trolled effectively, the temperature for initial rolling should not be less than $110^{\circ} \mathrm{C}$, that for secondary rolling should not be less than $90^{\circ} \mathrm{C}$, and that for final rolling should not be less than $70^{\circ} \mathrm{C}$. The completed asphalt layer should be protected effectively to avoid the drop of fuel, gasoline, grease or other organic impurities. As to lower seal coat, cement and cobble stabilized base should be inspected strictly according to the acceptance specifications. Any inconformity should be processed, the part which is higher than the design elevation should be scraped off and that less than the design elevation should be made up, so as to ensure the thickness of asphalt structure layer. Cement and cobble stabilized base should be cleaned carefully and flushed with watercart, so as to ensure good bond of asphalt surface and base course.

\section{CONCLUSION}

Currently, all colleges, universities, middle schools and primary schools require high quality physical education facilities. Therefore, as one of the infrastructures, during the construction of plastic track, the construction quality should be controlled strictly, so as to meet the demands of physical education and facilitate the development of physical education.

\section{CONFLICT OF INTEREST}

The author confirms that this article content has no conflict of interest.

\section{ACKNOWLEDGEMENTS}

Declared none.

\section{REFERENCES}

[1] X. Huang, "Study on Basic Construction Technology and Quality Control of Plastic Track," Chinese \& Foreign Entrepreneurs, no. 05, pp. 2013.

[2] S. Wang, "Analysis on Technical Essentials for Construction of Plastic Track" Henan Architecture, vol. 10, 2013.

[3] J. Zhao, "Discussion "on Construction Management of Sports Field," Urban Construction Theory Research (Electronic Edition), no. 03, 2014.

[4] D. Xiao, and Y. Zhu, "Discussion "on Construction Technology of 
Plastic Track," Urban Construction Theory Research (Electronic Edition), no. 04, 2013.

[5] G. Peng, G. Cen, and G. Hong, "Construction Technology and Quality Control of Plastic Playground," Shanxi Architecture, no. 01, 2010.
[6] Hao Wei, Cai Liangcai, Shao Bin, et al. "Calculation Model of Takeoff Capacity of Airport Independent Runway," Journal of Air Force Engineering University (Natural Science Edition), no. 08, 2010.

(C) Yarong Zheng; Licensee Bentham Open.

This is an open access article licensed under the terms of the (https://creativecommons.org/licenses/by/4.0/legalcode), which permits unrestricted, noncommercial use, distribution and reproduction in any medium, provided the work is properly cited. 